\title{
Diacylglycerol kinase as a possible therapeutic target for neuronal diseases
}

\author{
Yasuhito Shirai ${ }^{1 *}$ and Naoaki Saito ${ }^{2}$
}

\begin{abstract}
Diacylglycerol kinase (DGK) is a lipid kinase converting diacylglycerol to phosphatidic acid, and regulates many enzymes including protein kinase C, phosphatidylinositol 4-phosphate 5-kinase, and mTOR. To date, ten mammalian DGK subtypes have been cloned and divided into five groups, and they show subtype-specific tissue distribution. Therefore, each DGK subtype is thought to be involved in respective cellular responses by regulating balance of the two lipid messengers, diacylglycerol and phosphatidic acid. Indeed, the recent researches using DGK knockout mice have clearly demonstrated the importance of DGK in the immune system and its pathophysiological roles in heart and insulin resistance in diabetes. Especially, most subtypes show high expression in brain with subtype specific regional distribution, suggesting that each subtype has important and unique functions in brain. Recently, neuronal functions of some DGK subtypes have accumulated. Here, we introduce DGKs with their structural motifs, summarize the enzymatic properties and neuronal functions, and discuss the possibility of DGKs as a therapeutic target of the neuronal diseases.
\end{abstract}

\section{Introduction}

Diacylglycerol kinase (DGK) is the enzyme which phosphorylates diacylglycerol (DG) resulting in the production of phosphatidic acid (PA) [1-5]. Both DG and PA are very important signaling molecules. DG regulates the activity and localization of several proteins, including protein kinase C (PKC), chimerins, Unc-13, and Ras guanyl nucleotide-releasing protein (RasGRP). PA also activates several enzymes, including phosphatidylinositol 4-phosphate 5-kinase, mammalian target of rapamycin (mTOR), and atypical isoforms of PKC [6-10]. Therefore, DGK is thought to be a key enzyme that regulates numerous cellular responses by regulating balance of the two lipid messengers.

So far, ten mammalian subtypes of DGK have been cloned [11-20] and categorized into five groups depending on their structural motifs (Figure 1). All DGKs have two cysteine-rich regions ( $\mathrm{C} 1 \mathrm{~A}$ and $\mathrm{C} 1 \mathrm{~B}$ domains), except for DGK $\theta$ which has three regions, in the regulatory domain of the $\mathrm{N}$-terminal half of the molecule. These $\mathrm{C} 1$ domains of DGKs are homologous to those of PKC, which shows a

\footnotetext{
* Correspondence: shirai@kobe-u.ac.jp

'Laboratory of Chemistry and Utilization of Animal Production Resources, Applied Chemistry in Bioscience Division, Graduate School of Agricultural Science, Kobe University, Rokkodai-cho 1-1, Nada-ku, Kobe 657-8501, Japan Full list of author information is available at the end of the article
}

DG-dependent protein kinase activity. However, not all of the $\mathrm{C} 1$ domains but only those of DGK $\beta$ and $\gamma$ show the binding activity to DG [21]. All DGKs have a catalytic domain in the C-terminal half of the molecule, and the catalytic domain of Type II DGKs $(\delta, \eta$, and $\kappa)$ is separated into two portions by an insertion. In addition to these domains, they have different structures depending on their groups. Type I DGKs, DGK $\alpha, \beta$, and $\gamma$, have a recoverin homology (RVH) domain and an EF-hand motif. The $\mathrm{RVH}$ and EF-hand motif domains are thought to be a calcium ion sensor as described below. Type II DGKs, DGK $\delta, \eta$, and $\kappa$ have a pleckstrin homology $(\mathrm{PH})$ domain at $\mathrm{N}$-terminus and have sterile alpha motif (SAM) domain at C-terminus. Type III DGK, DGKe, has only the C1 domains. Type IV DGKs, DGK $\zeta$ and $\mathrm{\iota}$, have a myristoylated alanine rich protein kinase $C$ substrate phosphorylation site like region (MARCKS homology domain) between the $\mathrm{C} 1$ and catalytic domains, four ankyrin repeats, and a PDZ binding site at C-terminus. Finally, Type V DGK, DGK $\theta$ has a proline and glycine rich domain as well as a PH domain overlapping with a Ras associating domain. In addition, many splice variants are reported $[3,5]$.

Each subtype of DGK shows a subtype-specific tissue expression pattern (Table 1). For example, DGK $\beta, \gamma, \varepsilon, \zeta$, , and $\theta$ are localized in neurons and DGK $\alpha$ is reported to be localized in oligodendrocytes, although most DGKs are 


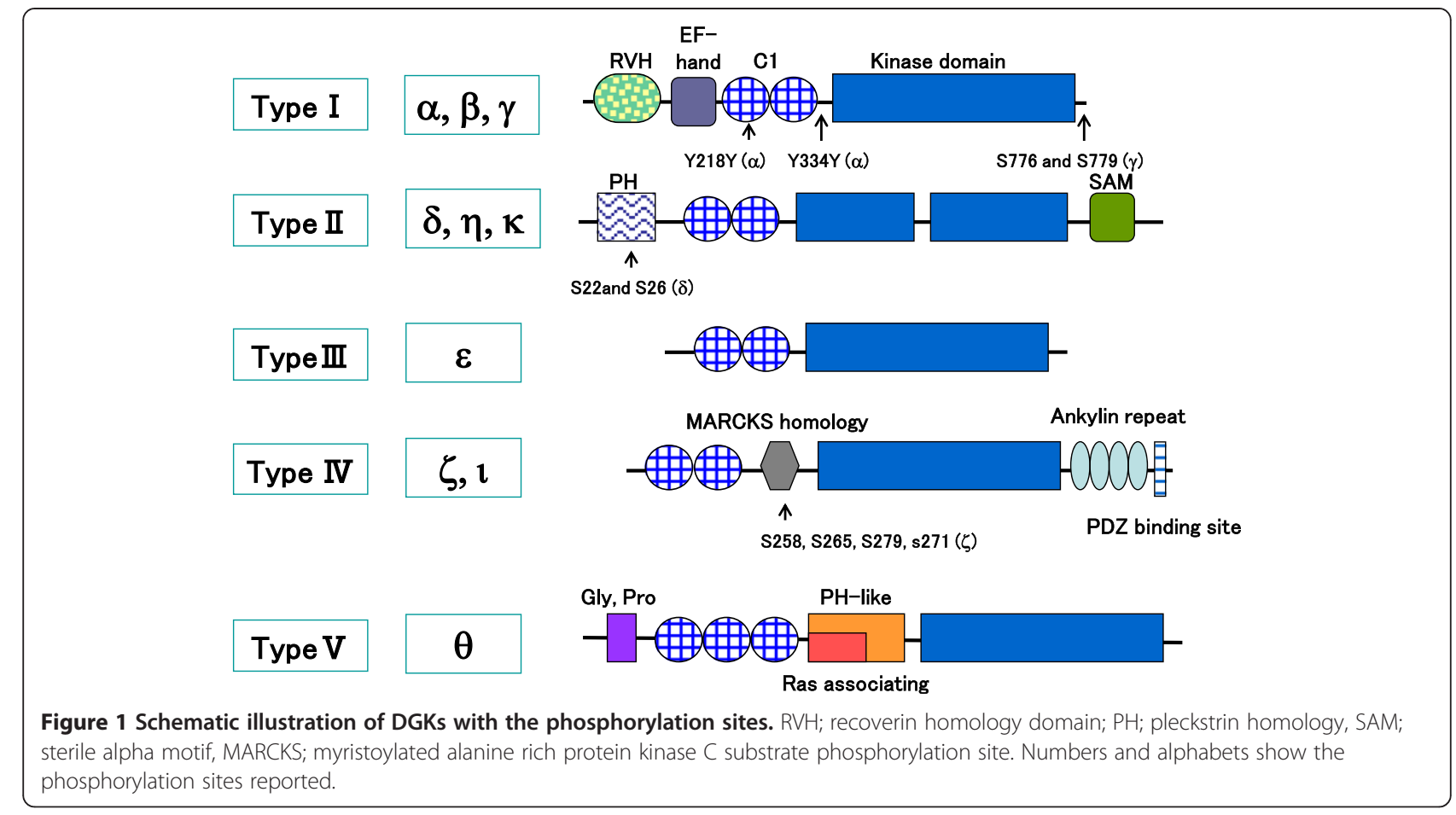

abundantly expressed in brain [22]. Specifically, DGK $\beta$ is expressed in caudate putamen, hippocampus, and cerebral cortex but not in cerebellum [12]. Instead, cerebellum expresses DGK $\gamma, \theta$, and $\zeta$. In addition, DGK $\alpha$ is highly enriched in immunological organs such as spleen and thymus. DGK $\zeta$ is highly expressed in thymus and brain, with substantial levels in skeletal muscle, heart, and pancreas $[16,23]$. DGK $\delta$ shows ubiquitous expression including skeletal muscle and testis [15,24]. The different expression patterns suggest a subtype-specific function of DGKs. Indeed, DGK $\alpha$ and $\zeta$ knockout (KO) mice demonstrate their importance in the immune system $[25,26]$ and DGK mice reveal its important role in cardiac hypertrophy [27]. Moreover, DGK $\delta$ plays a key role in insulin resistance in diabetes [28]. However, in spite of the abundant expression of DGKs in brain, their neuronal functions had been

Table 1 Characteristics of mammalian DGK subtypes

\begin{tabular}{|c|c|c|c|c|c|}
\hline & $\mathrm{MW}(\mathrm{KDa})$ & Localization & Enzymatic property & Function/Phenotype of KO & References \\
\hline a & 80 & $\begin{array}{l}\text { thymus, spleen }>>\text { kidny, } \\
\text { brain (oligodendrocytes) }\end{array}$ & $\begin{array}{c}\text { Ca2+, PS dependent R59022 } \\
\text { sensitive activated by PIP3, PI }(3,4) P 2\end{array}$ & $\begin{array}{l}\text { T cell anergy tumor invasion } \\
\text { insulin release }\end{array}$ & {$[11,25,33-37]$} \\
\hline$\beta$ & 90 & $\begin{array}{l}\text { brain }(C P>\text { hip, cortex, olf })> \\
\text { adrenal gland }>\text { small intestine }\end{array}$ & $\begin{array}{c}\text { Ca2+, PS dependent activated } \\
\text { by } \mathrm{PI}(4,5) \mathrm{P} 2\end{array}$ & $\begin{array}{l}\text { impairment of memory impairment of } \\
\text { memory (mania-like) severe seizure }\end{array}$ & {$[12,29-31,38,39]$} \\
\hline Y & 88 & $\begin{array}{c}\text { retina, brain }(\mathrm{Cb}, \mathrm{hip})>>\text { other } \\
\text { tissues }\end{array}$ & $\begin{array}{l}\text { Ca2+, PS dependent } \\
\text { R59022 sensitive }\end{array}$ & insulin release & {$[13,38]$} \\
\hline$\delta$ & 130 & skeletal muscle > testis, colon & Ca2+, PS independent & type II diabetes EGF signaling, seizure & {$[15,24,28,40,41]$} \\
\hline$\eta$ & $130-140$ & testis $>$ brain, lung, spleen $>$ heart & Ca2+ insensitive & $\begin{array}{l}\text { bipolar disorder (?), } \\
\text { Ras-Raf-MEK signaling }\end{array}$ & {$[16,42-45]$} \\
\hline K & 142 & testis > spleen, pracenta, & Ca2+ insensitive & hypospadias & {$[20,24]$} \\
\hline$\varepsilon$ & 64 & $\begin{array}{c}\text { retina,brain,testis }>\text { ovary }>> \\
\text { skeletal muscle heart }\end{array}$ & $\begin{array}{l}\text { Ca2 + independent selectively } \\
\text { for arachidonoyl DG }\end{array}$ & seizure & {$[14,46]$} \\
\hline$\zeta$ & 104 & $\begin{array}{l}\text { thymus }>\text { brain }(\mathrm{Cb} \text {, hip, olf })>> \\
\text { skeltal muscle, heart, pancreas }\end{array}$ & $\begin{array}{c}\text { Ca2 + insensitive Mg2+, } \\
\text { PS dependent }\end{array}$ & $\begin{array}{l}\text { T cell anergy, cell cycle control } \\
\text { spine maintenamce }\end{array}$ & {$[17,26,27,33,35,47,48]$} \\
\hline । & 130 & $\begin{array}{c}\text { retina > brain } \\
\text { (hip, } \mathrm{CP}, \text { cortex, } \mathrm{Cb}, \mathrm{Dg} \text { ) }\end{array}$ & Ca2+ insensitive & Ras GRP, Rap 1 signaling & {$[19,22,49,50]$} \\
\hline$\theta$ & 110 & $\begin{array}{l}\text { brain }(\mathrm{Cb}, \mathrm{hip})>> \\
\text { small intestine, liver etc. }\end{array}$ & Ca2+ insensitive & neurotransmitter release? & {$[18]$} \\
\hline
\end{tabular}


unknown for a long time. Recently, our and other groups have reported the importance of DGKs in brain functions [22,29-32]. In the following sections, we summarize the enzymatic properties and neuronal functions of DGKs for the development of drugs targeting the neuronal diseases.

\section{Review}

Regulation of the enzymatic activity

Although the enzymatic characteristics of all DGK subtypes have not been investigated, the activities of some DGKs are regulated by ionic detergents and phospholipids $[33,34]$. For example, the activities of DGK $\alpha$ and $\zeta$ depend on deoxycholate or cholic acid, so that a detergent, octyl glucoside, is used for the DGK assay. But the dependency of phospholipids seems to be subtype specific (Table 1). The activity of purified DGK $\alpha$ is remarkably enhanced by phosphatidylcholine (PC) but not by phosphatidylinositol (PI), while DGK $\zeta$ is activated by PI and phosphatidylserine (PS), but not so remarkably by PC [33]. DGK $\alpha$ is activated by PI3,4,5-trisphosphate $\left(\mathrm{PIP}_{3}\right)$ and $\mathrm{PI} 3,4$-bisphosphate $\left[\mathrm{PI}(3,4) \mathrm{P}_{2}\right]$, while DGK $\beta$ is activated by $\mathrm{PI} 4,5$-bisphosphate $\left[\mathrm{PI}(4,5) \mathrm{P}_{2}\right][34]$. Moreover, divalent cations including calcium and magnesium are also required for activation of DGK $\alpha$ and $\zeta[35,51]$. Specifically, Type I DGKs are believed to depend on calcium because they have the EF hand motif and RVH domains. The calcium dependency of DGK $\alpha$ has been clearly shown in vitro [35]. In addition to its role as a calcium sensor, the $\mathrm{N}$-terminus region has an inhibitory effect on the kinase activity $[52,53]$. Indeed, the $\mathrm{N}$-terminus region binds to its $\mathrm{C}$-terminal region containing the kinase domain and $\mathrm{C} 1$ domain in the absence of calcium [54]. However, the in vitro calcium-dependent activity of DGK $\beta$ and $\gamma$ has not been reported, although their EF-hands seem to bind to calcium and to regulate their kinase activity as well. Information of the enzymatic properties of each DGK subtype is not enough, and the precise enzymatic characterization should be carried out using the purified proteins under the respective optimized conditions.

All DGKs except for DGK $\beta$ are localized in cytoplasm in several cells, but some DGKs show the translocation to the plasma membrane and/or intracellular organelles in response to several stimulations [35,55-61]. For example, DGK $\gamma$ is translocated from the cytoplasm to the plasma membrane by calcium, phorbol ester, and purinergic receptor stimulations [55]. DGK $\alpha$ is also translocated to the plasma membrane by calcium [35], purinergic receptor stimulation [55], and T-cell receptor stimulation [56]. Moreover, DGK $\delta$ translocates to the plasma membrane in response to phorbol ester [57]. These are coincident with the fact that DG is produced on the plasma membrane and DGKs work there. In addition to the plasma membrane, DGK $\alpha$ is accumulated at the Golgi complex in the case of arachidonic acid and vitamin $\mathrm{E}$ stimulations
$[55,58]$. Furthermore, it is reported that DGK cated from the nucleus to the cytoplasm [59], and DGK $\theta$ and $\gamma$ are localized in the nucleus [60,61], consistent with the fluctuation of DG and PA contents in the nucleus [62-64]. These findings indicate that translocation is the key regulation mechanism to define where and how long each DGK works, and suggest that DGKs are important for the DG/PA metabolism in the plasma membrane and many organelles including nucleus and Golgi complex. In the case of DGK $\beta$, the plasma membrane localization seems to be a critical for its physiological function [29].

The translocation and activation of some DGKs are regulated by the phosphorylation reaction. We have revealed that DGKY is subtype-specifically phosphorylated by $\mathrm{PKC} \gamma$ at Ser-776 and Ser-779 upon the purinergic stimulation, resulting in up-regulation of its lipid kinase activity [65]. The membrane translocation of DGK $\delta$ is regulated by the phosphorylation at Ser-22 and Ser-26 by conventional/clas-

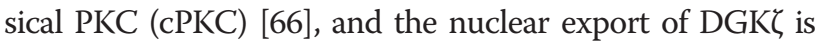
dependent on the phosphorylation at the MARCKS homology domain by PKC $\alpha$ [67]. Not only the serine phosphorylation but also the tyrosine phosphorylation is important: the membrane translocation of DGK $\alpha$ is dependent on phosphorylation at Tyr-334 (Tyr-335 in mouse) by Src family tyrosine kinases $[58,68,69]$. We also found that Tyr218 of DGK $\alpha$ is phosphorylated by c-Abl tyrosine kinase and the phosphorylation regulates serum-induced nuclear export of the enzyme [70]. These results indicate that the phosphorylation is one of the important regulation mechanisms for the spatial regulation of diacylglycerol signaling.

\section{DGK and brain function related to neuronal disease $D G K \beta$ and $\eta$ in mood disorder and memory loss}

Most subtypes of DGKs are abundant in brain (Table 1 and Ref. 22). Above all, high levels mRNA of DGK $\beta, \gamma, \zeta, \mathrm{l}$, and $\theta$ are detected in the neurons. In situ hybridization reveals that DGK $\beta$ is expressed in the caudate putamen, accumbens nucleus, and hippocampus [12]. Indeed, the protein expression of DGK $\beta$ in these regions is reported $[29,38]$. DGK $\beta$ is not present at the birth but its expression is rapidly increased from day 14 to day 28 , and is localized on the plasma membrane of spines [38], suggesting its importance in the neuronal network. Indeed, Goto et al. have reported that DGK $\beta$ is expressed at post synaptic sites in medium spiny neurons constituting the striatonigral and striatopallidal pathways $[39,71]$.

To investigate the neuronal functions of DGK $\beta$, we produced its $\mathrm{KO}$ mice and found that the primary cultured hippocampal neurons from DGK $\beta$ KO mice had less branches and spines compared to the wild type. In addition, long-term potentiation in the hippocampal CA1 region of the DGK $\beta$ KO mice was reduced, causing impairment of cognitive functions including spatial and long-term memories in Y-maze and Morris water-maze 
tests [29]. Furthermore, the KO mice showed impairment of emotion [30]: DGK $\beta$ KO mice spent longer time in the center area in the open field test, and in the open arms in elevated plus maze test than the wild type. On the other hand, DGK $\beta$ KO mice showed normal input-output relationship and behavior in prepulse inhibition test and social interaction test $[29,31]$. These results suggest that DGK $\beta$ $\mathrm{KO}$ mice have a mania-like behavior with memory loss, although their social skill and basal synaptic function are normal. The importance of DGK $\beta$ in the memory and emotion fits to the localization of DGK $\beta$ in hippocampus and caudate putamen, and its developmental changes [38].

Interestingly, the impairment of emotion and memory of DGK $\beta$ KO mice is rescued with the lithium treatment for ten days ([30], and unpublished data). The effect of lithium seems to involve in GSK3 $\beta$ inhibition [30]. These results suggest that $D G K \beta$ can be a possible target of memory loss and mood disorder. Indeed, DGK $\beta$ is reported as one of the learning-regulated genes in a research of age-dependent memory impairment [72]. This report indicates that histone acetylation is associated with age-dependent memory impairment and histone deacetylase inhibitor is expected as a drug for memory loss [73]. Moreover, one of the splice variant forms of human DGK $\beta$, which lacks 35 amino acids at the C-terminus but has an additional 4-amino-acid extension (DGK $\beta$ SV3; GenBank accession number AX032745), is associated with a human DGK $\beta$ EST that is annotated as differentially expressed in patients with mood disorders [74]. The splice variant form does not induce branches and spines [29], supporting the important role of DGK $\beta$ in spine formation.

Similarly, a mutation in DGK $\eta$ is reported to correlate with bipolar disorder [42-44], of which mRNA seems to be concentrated in hipocaumpus and dendate gyrus, although the expression level of the subtype in the brain is lower than in testis and tumor-derived cells [45]. Baum et al. have reported strong association between bipolar disorder and SNPs located in a gene encoding DGK $\eta$ by the genome-wide association study using the samples from European origin [42], and an increase in its mRNA level has been reported in some patients with bipolar disorder and schizophrenia [43,44], On the other hand, other studies have not confirmed the association [75-77]. The controversial results may be due to the races and methods employed. The precise experimental procedures would be necessary to prove the involvement of DGK $\eta$ in bipolar disorder.

$D G K \zeta$ and $\mathrm{I}$ in spine modulation and neurotransmitter release $D G K \zeta$, which is abundant in cerebellum, hippocampus, and olfactory bulb, is involved in spine maintenance $[47,78]$. For this function, its enzymatic activity and localization at the excitatory postsynaptic site by binding to some PSD95 family proteins through the PDZ- binding domain are critical. Interestingly, DGK $\zeta$ is detected in the nucleus in the hippocampal neurons but it is translocated to the cytoplasm by ischemia or kainate stimulation $[79,80]$, suggesting its role in the protection against ischemia. The subtype is also expected to be involved in the leptin receptor signaling because it associates with leptin [81]. However, detailed mechanisms are still unclear. DGKı also has the PDZ binding motif. The subtype is abundantly detected in hippocampus, dendate gyrus, and retina with moderate levels in the cortex, caudate-putamen, and thalamus $[19,22,82]$. However, the spine density and morphology of neurons in DGKı KO are normal [49]. Instead, DGKı regulates the presynaptic release during metabotropic glutamate receptor-dependent long-term potentiation [32,49]. Abnormal behaviors including impairment of memory and emotion of DGK $\zeta$ and ı KO mice have not been reported yet.

\section{$D G K \beta, \varepsilon$, and $\delta$ in seizure}

Seizure is a relatively common neuronal disease and at least three DGK subtypes are related to the disease. DGK $\varepsilon$ is uniformly expressed in brain, and its $\mathrm{KO}$ mice show an increased resistance to electroconvulsive and faster recovery than the wild type [46]. DGK $\delta$ is also associated to seizure, although its neuronal expression is very low: DGK $\delta$ gene is disrupted in a female patient with a de novo balanced translocation, who exhibits seizure with several dysfunctions, and electroencephalographic assessment of DGK $\delta$ mutant mice revealed abnormal epileptic discharges and electrographc seizures [40]. In addition, we also showed that seizure is severer in DGK $\beta$ KO mice than the wild type [31].

\section{Other DGKs}

DGK $\alpha$ is detected in oligodentrocytes, although the subtype is not enriched in brain $[11,83]$. DGK $\gamma$, which is predominantly localized in Purkinje cells and hippocampus, is present at birth and then gradually increased $[13,38]$. The mRNA expression of DGK $\theta$ is the highest in cerebellum and hippocampus [18] and it is suggested that DGK $\theta$ is involved in neurotransmitter release [84]. However, further examination would be necessary to understand physiological functions of DGK $\alpha, \gamma$, and $\theta$ in brain.

\section{Perspective}

As described above, some DGKs are important for neuronal functions. This is supported by their abundant and subtype-specific expression in brain. Generally, DGKs are likely involved in the spine formation and maintenance, contributing to higher brain function including memory and emotion. However, the detailed mechanisms of the DGK-mediated morphological change of spines and neurons are not clear. The membrane lipids including PA and DG seem to be the key molecules. Indeed, we found that 


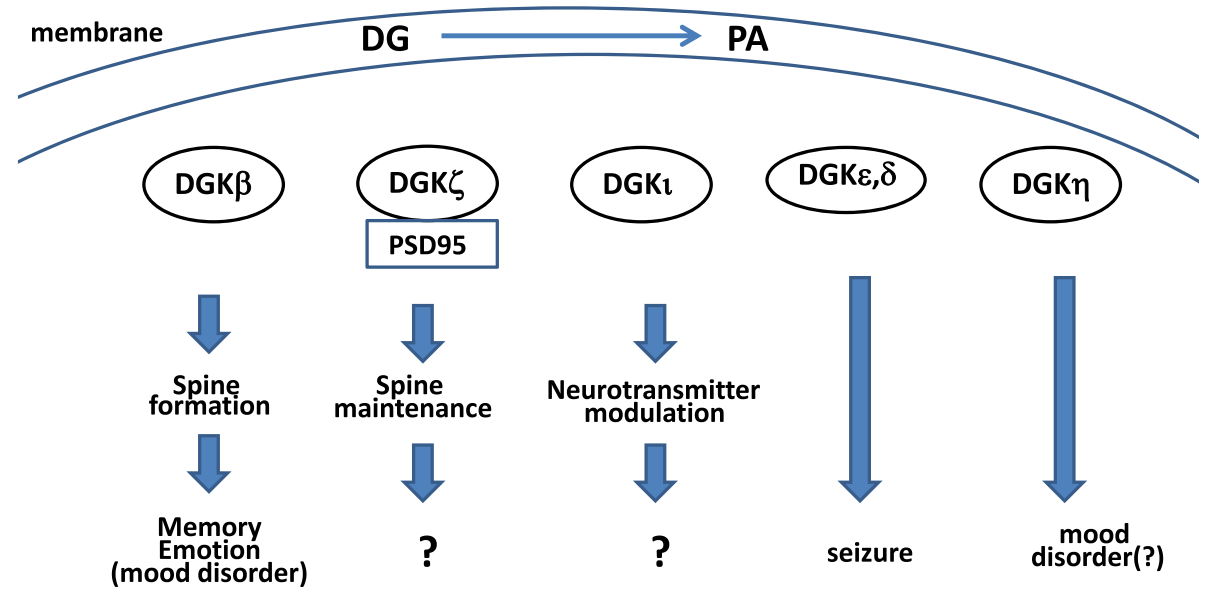

Figure 2 A schema of functions of DGKs in brain. DGK $\beta$ regulates spine formation and branching, contributing to higher brain functions including memory and emotion. DGK and I are involved in spine maintenance and neurotransmitter modulation, respectively. DGK $\varepsilon$ and $\delta$ are reported to be related to mood disorder. DGKn seems to be correlated to seizure. The control of membrane DG and PA is a key step, and protein-protein interaction like DGKZ and PSD95 is critical for the functions of DGKs.

mTOR and cPKC, which are activated by PA and DG respectively, are involved in the DGK $\beta$-induced neurite induction and branching [unpublished data], and the kinase activity is necessary for the DGK $\zeta$-mediated spine maintenance [22,47]. Alternatively, $\mathrm{PIP}_{2}$ and/or $\mathrm{PIP}_{3}$ may be additional key lipids because some DGKs can be activated by these inositol phospholipids, which are related to actin cytoskeletal rearrangement and membrane traffic [85]. On the other hand, unknown mechanism like a kinase-independent pathway may additionally exist. For example, we have recently found that there is a kinaseindependent pathway in the DGK $\beta$-induced neurite induction and branching [86]. Further investigations are necessary to reveal the whole story regulating the shape of the neuronal membrane by DGKs.

The facts described in this review suggest that some DGKs can be a target for the therapy of neuronal diseases including memory loss, mood disorder, and seizure. To develop the drugs targeting DGKs for these neuronal diseases, more precise experiments should be performed using human patients. For example, there is still no evidence that splice variant forms of DGK $\beta$ is expressed at protein level in human patients of bipolar disorder, although it is suggested to association with mood disorders [74]. More importantly, it is necessary to find subtypespecific inhibitor and/or activator of each DGK subtype because DGKs have subtype-specific and numerous physiological functions as summarized in Table 1. Recently, Sakane et al. have developed a new DGK assay method suitable for the high throughput screening [87]. Sakane's and our groups are collaborating to find specific inhibitor and/or activator of each DGK subtype. In near future, it will be possible to provide information about DGK-subtype specific inhibitor and/or activator which would be useful for the development of drugs targeting DGK for neuronal diseases.

DGKs are involved in not only neuronal diseases but also other diseases including diabetes, immuno-dysfunctions, and cardiovascular diseases. In addition, the correlation between cancer and DGK has been recently reported. For example, DGKa is involved in the progression of human hepatocellular carcinoma [88], and is necessary for the invasion of lung cancer [89]. These facts suggest that DGK can be a target of multiple diseases including diabetes, cancer, and neuronal diseases. Again, in addition to the comprehensive research to reveal subtype-specific functions DGKs, subtype-specific compounds would be necessary to develop drugs targeting DGKs without side effect.

\section{Conclusion}

In conclusion, some DGKs are involved in formation and maintenance of spines through the control of membrane lipid and protein-protein interactions, contributing higher brain functions including memory and emotion (Figure 2). Thus, some DGKs can be therapeutic target for neuronal diseases including mood disorder, memory loss, and seizure.

\section{Competing interests}

There is no financial and non-financial competing interests.

\section{Authors' contributions}

YS and NS conceived of the study and participated in its design and coordination and helped to draft the manuscript. All authors read and approved the final manuscript.

\section{Author details}

${ }^{1}$ Laboratory of Chemistry and Utilization of Animal Production Resources, Applied Chemistry in Bioscience Division, Graduate School of Agricultural Science, Kobe University, Rokkodai-cho 1-1, Nada-ku, Kobe 657-8501, Japan. ${ }^{2}$ Laboratory of Molecular Pharmacology, Biosignal Research Center, Kobe University, Rokkodai-cho 1-1, Nada-ku, Kobe 657-8501, Japan. 
Received: 17 January 2014 Accepted: 5 March 2014

Published: 7 April 2014

\section{References}

1. Topham MK, Prescott SM: Mammaliandiacylglycerol kinases, a family of lipid kinases with signaling functions. J Biol Chem 1999, 274:11447-11450.

2. van Bitterswijk WJ, Houssa B: Properties and functions of diacylglycerol kinases. Cell Signal 2000, 12:595-605.

3. Sakane F, Imai S, Kai M, Yasuda S, Kanoh H: Diacylglycerol kinases: why so many of them? Biochim Biophys Acta 2007, 1771:793-806.

4. Mérida I, Avila-Flores A, Merino E: Diacylglycerol kinases: at the hub of cell signaling. Biochem J 2008, 409:1-18.

5. Shulga YV, Topham MK, Epand RM: Regulation and functions of diacylglycerol kinases. Chemical Rev 2011, 111:6186-6208.

6. Jones DR, Sanjuan MA, Merida I: Type lalpha phosphatidylinositol 4phosphate 5-kinase is a putative target for increased intracellular phosphatidic acid. FEBS Lett 2000, 476:160-165.

7. Luo B, Prescott SM, Topham MK: Diacylglycerol kinase zeta regulates phosphatidylinositol 4-phosphate 5-kinase lalpha by a novel mechanism. Cell Signal 2004, 16:891-897.

8. Limatola C, Schaap D, Moolenaar WH, van Blitterswijk WJ: Phosphatidic acid activation of protein kinase C-zeta overexpressed in COS cells: comparison with other protein kinase $C$ isotypes and other acidic lipids. Biochem J 1994, 304:1001-1008.

9. Fang $Y$, Vilella-Bach M, Bachmann R, Flanigan A, Chen J: Phosphatidic acid-mediated mitogenic activation of mTOR signaling. Science 2001 294:1942-1945.

10. Almena M, Merida I: Shaping up the membrane: diacylgycerol coordinates spatial orientation of signaling. Trends Biochem Sci 2011, 36:583-603.

11. Sakane F, Yamada K, Kanoh H, Yokoyama C, Tanabe T: Porcine diacylglycerol kinase sequence has zinc finger and E-F hand motifs. Nature 2000, 334:345-348.

12. Goto K, Kondo H: Molecular cloning and expression of a 90-kDa diacylglycerol kinase that predominantly localizes in neurons. Proc Natl Acad Sci USA 1993, 90:7598-7602.

13. Goto K, Funayama M, Kondo H: Cloning and expression of a cytosckeleton-associated diacylglycerol kinase that is dominantly expressed in cerebellum. Proc Natl Acad Sci USA 1994, 91:13042-13046.

14. Tang W, Bunting M, Zimmerman GA, McIntyre TM, Prescott SM: Molecular cloning of a novel human diacylglycerol kianse highly selective for arachidonate-containing substrates. J Biol Chem 1996, 271:10237-10241.

15. Sakane F, Imai S, Kai M, Wada I, Kanoh H: Molecular cloning of a novel diacylglycerol kinase isozyme with a pleckstrin homology domain and a C-terminal tail similar to those of the EPH family of protein-tyrosine kinases. J Biol Chem 1996, 271:8394-8401.

16. Klauck TM, Xu X, Mousseau B, Jaken S: Cloning and characterization of a glucocorticoid-induced diacylglycerol kinase. J Biol Chem 1996, 271:19781-19788

17. Bunting M, Tang W, Zimmerman G, Mclntyre TM, Prescott SM: Molecular cloning and characterization of a novel human diacylglycerol kinase $\zeta$. $J$ Biol Chem 1996, 271:10230-10236.

18. Houssa B, Schaap D, van der Wal J, Goto K, Kondo H, Yamakawa A, Shibata M, Takenawa T, van Blitterswijk WJ: Cloning of a novel human diacylglycerol kinase (DGKn) containing three cysteine-rich domains, a prorine-rich region, and a pleckstrin homology domain with an overlapping Ras-associating domain. J Biol Chem 1997, 272:10422-10428.

19. Ding L, Traer E, Mclntyre TM, Zimmerman GA, Prescott SM: The cloning and characterization of a novel human diacylglycerol kinase, DGKı. J Biol Chem 1998, 273:32746-32752.

20. Imai S, Kai M, Yasuda S, Kanoh H, Sakane F: Identification and characterization of a novel human type II diacylglycerol kinase, DGKK. J Biol Chem 2005, 280:39870-39881.

21. Shindo M, Irie K, Masuda A, Ohigashi H, Shirai Y, Miyasaka K, Saito N: Synthesis and Phrobol ester biniding of the cysteine-rich domains of diacylglycerol kinase (DGK) isozymes. J Biol Chem 2003, 278:18448-18454.

22. Tu-Sekine B, Raben DM: Regulation and roles of neuronal diacylglycerolkinases: A lipid perspetive. Crit Rev Biochem Mol Biol 2011, 46:353-364.

23. Goto K, Kondo H: A 104 kDa diacylglycerol kinase containing ankyrinlike repeats localize in the cell nucleus. Proc Natl Acad Sci USA 1996, 93:11196-11201.
24. Sakai H, Sakane F: Recent progress on type II diacylglycerol kinases: the physiological functions of diacylglycerol kinase $\delta, \eta$ and $k$ and their involvement in disease. J Biochem 2012, 152:397-406.

25. Zha Y, Marks R, Ho AW, Peterson AC, Janardhan S, Brown I, Praveen K, Stang S, Stone JC, Gajewski TF: T cell anergy is reversed by active Ras and is regulated by diacylglycerol kinase-a. Nature Immunol 2006, 11:1166-1173.

26. Olenchock BA, Guo R, Carpenter JH, Jordan M, Topham MK, Koretzky GA, Zhong XP: Distruption of diacylglycerol metabolism impairs the induction of T cell anergy. Nat Immunol 2006, 11:1174-1181.

27. Goto K, Nakano T, Hozumi Y: Diacylglycerol kinase and animal models: the pathophysiological roles in the brain and heart. Advan Enzyme Regul 2006, 46:192-202.

28. Chibalian AV, Leng Y, Vieira E, Krook A, Bjomholm M, Krook A, Bjo Rnholm M, Long YC, Kotova O, Zhong Z, Sakane F, Steiler T, Nylen C, Wang J, Laakso M, Topham MK, Gilbert M, Wallberg-Henriksson H, Zierath JR: Down regulation of diacylglycerol kinase delta contributes to hyperglycemia-induced insulin resistance. Cell 2008, 132:375-386.

29. Shirai Y, Kouzuki K, Kakefuda K, Moriguchi S, Ohyagi A, Horie K, Morita S, Shimazawa M, Fukunaga K, Takeda J, Saito N, Hara H: Essential role of neuron-enriched diacylglycerol kinase (DGK), DGK $\beta$ in neurite spine formation, contributing to cognitive function. PLOS ONE 2010, 5:e11602.

30. Kakefuda K, Oyagi A, Ishisaka M, Tsumura K, Shimazawa M, Yokota K, Shirai Y, Horie K, Saito N, Takeda J, Hara H: Diacylglycerol kinase $\beta$ knockout mice exhibit lithium-sensitive behavioral abnormalities. PLOS ONE 2010, 5:e13447.

31. Ishisaka M, Tsuruma K, Shimazawa M, Shirai Y, Saito N, Hara H: Increased seizure susceptibility in a mouse with diacylglycerol kinase $\beta$ deficiency Neurosci Med 2013, 4:117-122.

32. Kim K, Yang J, Kim E: Diacylglycerol kinases in the regulation of dendritic spines. J Neurochem 2012, 112:577-587.

33. Kanoh $\mathrm{H}$, Kondoh $\mathrm{H}$, Ono $\mathrm{T}$ : Diacylglycerol kinase from pig brain. J Biol Chem 1983, 258:1767-1774.

34. Cipres A, Carrasco S, Merino E, Díaz E, Krishna UM, Falck JR, Martínez-A C, Mérida I: Regulation of diacylglycerol kinase a by phosphoinositide 3kinase lipid products. J Biol Chem 2003, 278:35629-35635.

35. Sakane F, Yamada K, Imai S, Kanoh H: Porcine $80-\mathrm{kDa}$ diacylglycerol kinse is a calcium-binding and calcium/phospholipid-dependent enzyme and undergoes calcium-dependent translocation. J Biol Chem 1991, 266:7096-7100.

36. Goto K, Watanabe M, Kondo H, Yuasa H, Sakane F, Kanoh H: Gene cloning, sequence, expression and in situ localization of $80 \mathrm{kDa}$ diacylglycerol kinase specific to oligodendrocyte of rat brain. Mol Brain Res 1992, 16:75-87.

37. Kurohane-Kaneko Y, Kobayashi Y, Motoki K, Nakata K, Miyagawa S, Yamamoto M, Hayashi D, Shirai Y, Sakane F, Ishikawa T: Depression of type I diacylglycerol kinases in pancreatic -cells from male mice results in impaired insulin secretion. Endocrinology 2013, 154:4089-4098.

38. Adachi N, Oyasu M, Taniguchi T, Yamaguchi Y, Takenaka R, Shirai Y, Saito N: Immunocytochemical localization of a neuron-specific diacylglycerol kinase $\beta$ and $\gamma$ in the developing rat brain. Mol Brain Res 2005 139:288-299.

39. Hozumi $Y$, Goto K: Diacylglycerol kinase $\beta$ in neurons: Functional implications at the synapse and in disease. Adv Biol Reg 2012, 52:315-325.

40. Leach NT, Sun Y, Michaud S, Zheng Y, Ligon KL, Ligon AH, Sander T, Korf BR, Lu W, Harris DJ, Gusella JF, Maas RL, Quade BJ, Cole AJ, Kelz MB, Morton CC: Disruption of diacylglycerol kinase delta (DGKD) associated with seizures in humans and mice. Am J Hum Genet 2007, 80:792-799.

41. Crotty T, Cal J, Sakne F, Taketomi A, Prescott SM, Topham MK: Diacylglycerol kinase $\delta$ regulates protein kinase $C$ and epidermal growth factor receptor signaling. Proc Natl Acad Sci USA 2006, 103:15485-15490.

42. Baum AE, Akula N, Cabanero M, Cardona I, Corona W, Klemens B, Schulze TG, Cichon S, Rietschel M, Nöthen MM, Georgi A, Schumacher J, Schwarz M, Abou Jamra R, Höfels S, Propping P, Satagopan J, Detera-Wadleigh SD, Hardy J, McMahon FJ: A genome-wide association study implicates diacylglycerol kinase eta (DGKH) and several other genes in the etiology of bipolar disorder. Mol Psychiatry 2008, 13:197-207.

43. Moya PR, Murphy DL, McMahon FJ, Wendland JR: Increased gene expression of diacylglycerol kinase eta in bipolar disorder. Int J Neuropsychophamacol 2010, 13:1127-1128.

44. Ollila HM, Soronen P, Silander K: Findings from bipolar disorder genomewide association studies replicate in a Finish bipolar family-cohort. Mol Psychiaty 2009, 14:351-353. 
45. Murakami T, Sakane F, Imai S, Houkin K, Kanoh H: Identification and characterization of two splice variants of human diacylglycerol kinase $\eta$. J Biol Chem 2003, 278:34364-34372.

46. de Turco EB R, Tang W, Topham MK, Topham MK, Sakane F, Marcheselli VL, Chen C, Taketomi A, Prescott SM, Bazan NG: Diacylglycerol kinase $\varepsilon$ regulates seizure susceptibility and long-term potentiation through arachidonoyl-inositol lipid signaling. Proc Natl Acd Sci USA 2001, 98:4740-4745.

47. Kim K, Yang J, Zhong XP, Kim MH, Kim YS, Lee HW, Han S, Choi J, Han K, Seo J, Prescott SM, Topham MK, Bae YC, Koretzky G, Choi SY, Kim E: Synaptic removal of diacylglycerol by DGK and PSD-95 regulates dendritic spine maintenance. EMBO J 2009, 28:1170-1179.

48. Kohyama-Koganeya A, Watanabe M, Hotta Y: Molecular cloning of a diacylglycerol kinase isozyme predominantly expressed in rat retina. FEBS Lett 1997, 409:258-264.

49. Yang J, Seo J, Nair R, Han S, Jang S, Kim K, Han K, Paik SK, Choi J, Lee S, Bae YC, Topham MK, Prescott SM, Rhee JS, Choi SY, Kim E: DGKı reguilates presynaptic release during mGluR-dependent LTD. EMBO J 2011, 30:165-180.

50. Reier DS, Higbee J, Lund KM, Sakane F, Prescott SM, Topham MK: Diacylglycerol kinase । regulates Ras guanyl-releasing protein 3 and inhibits Rap1 signaling. Proc Natl Acad Sci USA 2005, 102:7595-7600.

51. Kato M, Takenawa T: Purification and characterization of membranebound and cytosolic forms of diacylglycerol kinase from rat brain. $J$ Biol Chem 1990, 265:794-800

52. Jiang Y, Qian W, Hawes JW, Walsh JP: A domain with homology to neuronal calcium sensors is required for calcium-dependent activation of diacylglycerol kinase a. J Biol Chem 2000, 275:34092-34099.

53. Sanjuan $M$, Jones DR, Izuierdo $M$, Mérida I: Role of diacylglycerol kinase a in the attenuation of receptor signaling. J Cell Biol. 2001, 153:207-219.

54. Takahashi M, Yamamoto T, Sakai H, Sakane F: Calcium negatively regulates an intramolecular interaction between the $\mathrm{N}$-terminal recoverin homology and EF-hand motif domains and the C-terminal C1 and catalytic domains of diacylglycerol kinase a. Biochem Biophys Res Comun 2012, 423:571-576.

55. Shirai $Y$, Segawa S, Kuriyama M: Subtype-specific translocation of diacylglycerol kinase $\alpha$ and $\gamma$ and its correlation with protein kinase $C$. J Biol Chem 2000, 275:24760-24766.

56. Sanjua'n MA, Pradet-Balade B, Jones DR, Martínez-A C, Stone JC, Garcia-Sanz JA, Mérida I: T Cell Activation in vivo targets diacylglycerol kinase to the membrane: A novel mechanism for Ras Attenuation. J Immunol 2003, 170:2877-2883.

57. Imai S, Sakane F, Kanoh H: Phorbol ester-regulated oligomerrization of diacylglycerol kinase $\delta$ linked to its phosphorylation and translocation. J Biol Chem 2002, 277:35323-35332.

58. Fukunaga-Takenaka R, Shirai Y, Yagi K, Adachi N, Sakai N, Merino E, Merida I, Saito N: Importance of chroman ring and tyrosine phosphorylation in the subtype-specific translocation and activation of diacylglycerol kinase alpha by d-a-tocophenol. Genes Cells 2005, 10:311-319.

59. Topham M, Bunting M, Zimmerman GA, Adachi N, Sakai N, Merino E, Merida I, Saito N: Protein kinase C regulates the nuclear localization of diacylglycerol kinase-乙. Nature 1998, 394:697-700.

60. Tabellini G, Bortul R, Santi S, Riccio M, Baldini G, Cappellini A, Billi AM, Berezney R, Ruggeri A, Cocco L, Martelli AM: Diacylglycerol kinase- $\theta$ is localized in the speckle domains of the nucleus. Exp Cell Res 2003, 287:143-154.

61. Matsubara T, Shirai Y, Miyasaka K, Murakami T, Yamaguchi Y, Ueyama T, Kai M, Sakane F, Kanoh H, Hashimoto T, Kamada S, Kikkawa U, Saito N: Nuclear transportation of diacylglycerol kinase $\gamma$ and its possible function in the nucleus. J Biol Chem 2006, 281:6152-6164.

62. Martelli AM, Tabellini G, Bortul R, Manzoli L, Bareggi R, Baldini G, Grill V Zweyer M, Narducci P, Cocco L: Enhanced nuclear diacylglycerol kinase activity in response to a mitogenic stimulation of quiescent Swiss 3T3 cells with insulin-like growth factor I. Cancer Res 2000, 60:815-821.

63. Irvine R: Nuclear lipid signaling. SCi STKE 2000, re1.

64. Martelli AM, Fala F, Faenza I, Billi AM, Cappellini A, Manzoli L, Cocco L: Metabolism and signaling activities of nuclear lipids. Cell Mol Life Sci 2004, 61:1143-1156

65. Yamaguchi Y, Shirai Y, Matsubara T, Sanse K, Kuriyama M, Oshiro N, Yoshino K, Yonezawa K, Ono Y, Saito N: Phosphorylation and up-regulation of diacylglycerol kinase $\gamma$ via its interaction with protein kinase $C \gamma$. J Biol Chem 2006, 281:31627-31637.

66. Imai S, Kai M, Yamada K, Kanoh H, Sakane F: The plasma membrane translocation of diacylglycerol kinase $\delta 1$ is negatively regulated by conventional protein kinase C-dependent phosphorylation at Ser-22 and Ser-26 within the pleckstrin homology domain. Biochem J 2004, 382:957-966

67. Luo B, Prescott SM, Topham MK: Association of diacylglycerol kinase $\zeta$ with protein kinase $C$ a: spatial regulation of diacylglycerol signaling. J Cell Biol 2003, 160:929-937.

68. Baldanzi G, Cutrupi S, Chianale F, Gnocchi V, Rainero E, Porporato P, Filigheddu N, van Blitterswijk WJ, Parolini O, Bussolino F, Sinigaglia F Graziani A: Diacylglycerol kinase-a phosphorylation by Src on Y335 is required for activation, membrane recruitment and Hgf-induced cell motility. Oncogene 2007, 27:942-956.

69. Merino E, Avila-Flores A, Shirai Y, Moraga I, Saito N, Mérida I: Lck-dependent tyrosine phosphorylation of diacylglycerol kinase a regulates its membrane association in T cells. J Immunol 2008, 180:5805-5815.

70. Matsubara M, Ikeda M, Kiso Y, Sakuma M, Yoshino K, Sakane F, Merida I, Saito N, Shirai Y: c-Abl tyrosine kinase regulates serum-induced nuclear export of diacylglycerol kinase a by phosphorylation at Tyr218. J Biol Chem 2012, 287:5507-5517.

71. Hozumi Y, Fukuya M, Adachi N, Saito N, Otani K, Kondo H, Watanabe M, Goto K: Diacylglycerol kinase $\beta$ accumulates on the perisynaptic site of medium spiny neurons in the striatum. Eur J Neurosci 2008, 28:2409-2422.

72. Peleg S, Sananbenesi F, Zovoitis A, Burkhardt S, Bahari-Javan S, Agis-Balboa RC, Cota P, Wittnam JL, Gogol-Doering A, Opitz L, Salinas-Riester G, Dettenhofer M, Kang $\mathrm{H}$, Farinelli $\mathrm{L}$, Chen W, Fischer A: Alteren histone acetylation is associated with age-dependent memory impairment in mice. Science 2010, 328:753-756

73. Xu K, Dai XL, Haung HC, Jiang ZF: Targeting HDACs: A Promising Therapy for Alzheimer's Disease. Oxid Med Cell Longev 2011, ID 143269.

74. Caricasole A, Bettini E, Sala C, Roncarati R, Kobayashi N, Caldara F, Goto K, Terstappen GC: Molecular cloning and characterization of the human diacylglycerol kinase $\beta$ (DGK $\beta$ ) gene. J Biol Chem 2002, 277:4790-4796.

75. Tesli M, Kahler AK, Andreassen BK: No association between DGKH and bipolar disorder in a Scandinavian case-control sample. Psychiatr Genet 2009, 19:269-272.

76. Sklar P, Smoller JW, Fan J, Ferreira MA, Perlis RH, Chambert K, Nimgaonkar VL, McQueen MB, Faraone SV, Kirby A, de Bakker PI, Ogdie MN, Thase ME, Sachs GS, Todd-Brown K, Gabriel SB, Sougnez C, Gates C, Blumenstiel B, Defelice M, Ardlie KG, Franklin J, Muir WJ, McGhee KA, Maclntyre DJ, McLean A, VanBeck M, McQuillin A, Bass NJ, Robinson M, Lawrence J, Anjorin A, Curtis D, et al: Whole-genome asscociation study of bipolar disorder. Mol Psychiary 2008, 13:558-569.

77. Yosifova A, Mushiroda T, Stoianov D, Vazharova R, Dimova I, Karachanak S, Zaharieva I, Milanova V, Madjirova N, Gerdjikov I, Tolev T, Velkova S, Kirov G, Owen MJ, O'Donovan MC, Toncheva D, Nakamura Y: Case-control association study of 65 candidates genes revealed a possible association of a SNP of HTR5A to be a factor susceptible to bipolar disease in Bulgarian population. J Affect Disord 2009, 117:87-97.

78. Yakubchyk Y, Abramovici H, Maillet JC, Daher E, Obagi C, Parks RJ, Topham MK, Gee SH: Regulation of nerurite outgrowth in N1E-115 cells through PDZ-mediated recruitment of diacylglycerol kinase $\zeta$. Mol Cell Biol 2005, 25:7289-7302

79. Ali H, Nakano T, Saino-Saito S, Hozumi Y, Katagiri Y, Kamii H, Sato S, Kayama $\mathrm{T}$, Kondo $\mathrm{H}$, Goto K: Selective translocation of diacylglycerol kinase $\zeta$ in hippocampal neurons under transient forebrain ischemia. Neurosci Lett 2004, 372:190-195.

80. Saino-Saito S, Hozumi Y, Goto K: Excitotoxity by kainate-induced seizure diacylglycerol kinase $\zeta$ to shuttle from the nucleus to the cytoplasm in hippocampal neurons. Neurosci Lett 2011, 494:185-189.

81. Liu Z, Chang GQ, Leibowitz SF: Diacylglycerol kinase zeta in hypothalamus interacts with long form leptin receptor. Relation to dietary fat and body weight regulation. J Biol Chem 2001, 276:5900-5907.

82. Sommer W, Arlinde C, Caberlotto L, Thorsell A, Hyytia P, Heilig M: Differential expression of diacylglycerol kinase iota and L18A mRNAs in the brains of alcohol-preferring AA and alcohol-avoiding ANA rats. $\mathrm{Mol}$ Psychiatry 2001, 6:103-108.

83. Goto K, Kondo H: Heterogeneity of diacylglycerol kinase in terms of molecular structure, biochemical characteristics and gene expression localization in the brain. J Lipid Mediat Cell Signal 1996, 14:251-257.

84. Tu-Sekine B, Raben DM: Regulation of DGK $\theta$. J Cell Physiol 2009, 220:548-552

85. Takenawa T, Suetsugu S: The WASP-WAVE protein network: connecting the membrane to the cytoskeleton. Nature Rev Mol Cell Biol 2007, 8:37-48.

86. Kano T, Kouzuki T, Mizuno S, Ueda S, Yamanoue M, Sakane F, Saito N, Shirai Y: Both the $\mathrm{C} 1$ domain and a basic amino acid cluster at the $\mathrm{C}$-terminus are 
important for the neurite and branch induction ability of DGK $\beta$.

Biochem Biophys Res Comun 2014, in press.

87. Sato M, Liu K, Sasaki S, Kunii N, Sakai H, Mizuno H, Saga H, Sakane F:

Evaluations of the selectivities of the diacylglycerol kinase inhibitors R59022 and R59949 among diacylglycerol kinase isozymes using a new non-radioactive assay method. Pharmacology 2013, 92:99-107.

88. Takeishi K, Taketomi A, Shirabe K, Toshima T, Motomura T, Ikegami T, Yoshizumi T, Sakane F, Maehara Y: Diacylglycerol kinase alpha enhances hepatocellular carcinoma progression by activation of Ras-Raf-MEK-ERK pathway. J Hepatology 2012, 57:77-83.

89. Rainero E, Caswell PT, Muller PAJ, Grindlay J, McCaffrey MW, Zhang Q,

Wakelam MJ, Vousden KH, Graziani A, Norman JC: Diacylglycerol kinase a controls RCP-dependent integrin trafficking to promote invasive migration. J Cell Biol 2012, 196:277-295.

doi:10.1186/1423-0127-21-28

Cite this article as: Shirai and Saito: Diacylglycerol kinase as a possible therapeutic target for neuronal diseases. Journal of Biomedical Science 2014 21:28.

\section{Submit your next manuscript to BioMed Central and take full advantage of:}

- Convenient online submission

- Thorough peer review

- No space constraints or color figure charges

- Immediate publication on acceptance

- Inclusion in PubMed, CAS, Scopus and Google Scholar

- Research which is freely available for redistribution 